\title{
Corrosion of WC-VC-Co Hardmetal in Neutral Chloride Containing Media
}

\author{
C. N. Machio, ${ }^{1}$ D. S. Konadu, ${ }^{2,3}$ J. H. Potgieter, ${ }^{4}$ S. Potgieter-Vermaak, ${ }^{5,6}$ and J. Van der Merwe \\ ${ }^{1}$ Council for Scientific and Industrial Research (CSIR), Materials Science and Manufacturing, P.O. Box 395, Pretoria 0001, South Africa \\ ${ }^{2}$ DST/NRF Centre of Excellence in Strong Materials, and School of Chemical and Metallurgical Engineering, \\ University of Witwatersrand, Johannesburg, Wits 2050, South Africa \\ ${ }^{3}$ Materials Science and Engineering Department, University of Ghana, Legon, Accra, Ghana \\ ${ }^{4}$ School of Research, Enterprise and Innovation, Manchester Metropolitan University, Oxford Road, Manchester M1 5GD, UK \\ ${ }^{5}$ School of Science and the Environment, Manchester Metropolitan University, Oxford Road, Manchester M1 5GD, UK \\ ${ }^{6}$ School of Chemistry, University of the Witwatersrand, Johannesburg, Private Bag X3, Wits 2050, South Africa
}

Correspondence should be addressed to C. N. Machio; cmachio@csir.co.za

Received 29 November 2012; Accepted 20 December 2012

Academic Editors: G. Marginean and R. Wang

Copyright (C) 2013 C. N. Machio et al. This is an open access article distributed under the Creative Commons Attribution License, which permits unrestricted use, distribution, and reproduction in any medium, provided the original work is properly cited.

\begin{abstract}
The effect of varying VC content on the corrosion behavior of WC-10 wt\% Co hardmetals in sodium chloride $(\mathrm{NaCl})$ and synthetic mine water (SMW) solutions has been investigated using anodic polarization scans and surface analytical methods. It is shown that the polarization behavior is active-pseudopassive in $\mathrm{NaCl}$ and active in SMW regardless of the VC content, while the corrosion resistance is poorer and independent of $\mathrm{VC}$ content in $\mathrm{NaCl}$ but better at high $\mathrm{VC}$ contents in SMW. The corrosion behavior of samples is explained using the effect of $\mathrm{VC}$ on the chemical composition of the binder.
\end{abstract}

\section{Introduction}

Corrosion is an important surface degradation process in some, if not all, applications of tungsten-carbide-(WC-) cobalt- (Co-) based hardmetals. Applications like tools for machining of metals [1] and for wear resistance in the mining industry [1] expose the WC-Co to fluids that can be corrosive, leading to a reduced useful life. The Co binder is the least corrosion resistant constituent [2], and efforts to improve WC-Co corrosion resistance have involved altering the chemical composition of the binder by introducing more corrosion resistant elements. Nickel [3], and chromium [4] especially, and recently, ruthenium [5] have been shown to markedly improve the corrosion resistance of WC-Co-based hardmetals.

The corrosion resistance of WC-Co can also be improved by some transition carbides, which have been usually added in small amounts. Chromium carbide $\left(\mathrm{Cr}_{3} \mathrm{C}_{2}\right)$, for example, added to WC-Co in amounts of about $0.5 \mathrm{wt} . \%$ markedly improves corrosion resistance [6]. The effect of vanadium carbide (VC) has not been as straight forward as that of chromium carbide. Earlier studies [6] found small additions of VC to WC-Co had at best a neutral effect on the corrosion resistance. Subsequent studies by other researchers, using higher amounts of VC have indicated otherwise. For example, studies in hydrochloric and sulphuric acids have indicated that $10 \mathrm{wt} \% \mathrm{VC}$ improves the corrosion resistance of high Co content WC-Co [7]. This result has been confirmed by the current authors [8] who have shown that the corrosion resistance, determined from the corrosion current density at the free corrosion potential, increases with increasing VC content. The current article is extending the corrosion study of the materials to neutral chloride electrolytes to determine whether the improved corrosion resistance is solution independent. It has happened that observations made on the corrosion of WC-Co in acidic electrolytes do not appear to be reproduced in tests that use neutral chloride containing solutions [9]. 
TABLE 1: Nominal chemical composition and magnetic properties of test specimens.

\begin{tabular}{lcc}
\hline Specimen & Approx. vol\% Co & $\begin{array}{c}\text { Magnetic saturation } \\
(4 \pi \sigma)\left(\mathrm{G} \mathrm{cm}^{3} \mathrm{~g}^{-1}\right)\end{array}$ \\
\hline WC-10Co & 16 & 172 \\
WC-0.4VC-10Co & 16 & 185 \\
WC-10VC-12Co & 17 & 230 \\
WC-27VC-11Co & 13 & 194 \\
\hline
\end{tabular}

\section{Experimental}

2.1. Materials. The nominal composition (wt.\%) of the test materials and their magnetic saturation levels are given in Table 1. The microstructures of the specimens are fully described elsewhere [8]. The VC content took values of $0,0.4,10$, and $27 \mathrm{wt} \%$. However, the VC, at the 10 and 27 wt.\% content, occurred as the double carbide $(\mathrm{W}, \mathrm{V}) \mathrm{C}$ because WC dissolves in VC during sintering [10]. For easier referencing, the samples will be referred to using their $\mathrm{VC}$ content. The target binder content was $10 \mathrm{wt} \% \mathrm{Co}$ for all the specimens, but samples $10 \mathrm{VC}$ and $27 \mathrm{VC}$ had 12 and $11 \mathrm{wt} \%$ Co, respectively. Comparison between the samples is still possible because the effect of cobalt content on the corrosion behavior of WC-Co hardmetals is known. For example, it is known that the current densities at (free) open circuit potential are a function of Co content, and in acidic solutions, the current densities increase with increasing Co content [11].

The magnetic saturation of the specimens increased with the introduction of VC and with Co content (Table 1). Cobalt is the magnetic phase and the higher values with higher Co contents are expected. The magnetic saturation provides a measure of the solute content of the binder and is a quick technique for determining the quality of sintered WC-Co [12]. Generally, and within limits, the magnetic saturation decreases linearly with an increase of $\mathrm{W}$ content of the binder $[13,14]$.

2.2. Electrochemical Measurements. Electrochemical measurements were carried out using the conventional setup of a three-electrode cell in which the test specimen is the working electrode, an inert material, in the case here, graphite rod, is the counter electrode (CE) and a reference electrode against which all potentials are reported. The reference electrode used was a silver/silver chloride electrode (SSE) (in saturated $\mathrm{KCl}$ ) and was connected to the test cell via a Luggin probe capillary. All tests were done at room temperature and the electrolytes were neither deaerated nor aerated during testing.

The electrolytes used were $1 \mathrm{M}$ sodium chloride $(\mathrm{NaCl})$ and synthetic mine water (SMW) whose composition is given in Table 2. They were chosen to represent the mining environment where WC-Co is used to combat wear [23]. The composition of the SMW given in Table 2 is the most aggressive mine water found in the gold mines of South Africa $[15,24]$.

Test samples were polished to a $1 \mu \mathrm{m}$ surface finish after being made electrically conductive by attaching an aluminum
TABLE 2: Synthetic mine water composition [15].

\begin{tabular}{lc}
\hline Compound & Concentration $(\mathrm{mg} / \mathrm{L})$ \\
\hline $\mathrm{Na}_{2} \mathrm{SO}_{4}$ & 1237 \\
$\mathrm{CaCl}_{2}$ & 1038 \\
$\mathrm{MgSO}_{4}$ & 199 \\
$\mathrm{NaCl}$ & 1380 \\
\hline
\end{tabular}

sticker tape to one face in a cold-mounted mold. After immersion in the electrolytes, the open circuit potential (OCP) was allowed to stabilize for two hours. Potentiodynamic anodic polarisation measurements were done using an Autolab potentiostat/galvanostat connected to a personal computer with a General Purpose Electrochemical System (GPES) software. As in an earlier study [8], potential was varied from $-600 \mathrm{mV}$ to $+1200 \mathrm{mV}$ at a scan rate of $2 \mathrm{mV} / \mathrm{s}$ for all the samples. This scan rate was similar to those used in literature $[25,26]$. The corrosion potential $\left(E_{\text {corr }}\right)$, corrosion current density $\left(i_{\text {corr }}\right)$, and corrosion rates were retrieved from the corrosion measurement data using the intersection of the anodic and cathodic Tafel lines.

Chronoamperometry measurements were performed immediately on specimens at the end of their potential sweeps to investigate the corrosion products on their surfaces. The measurements were done for eight hours at potentials selected from the anodic polarisation curves.

Samples were characterised for phases before and after corrosion testing using a Phillips PW 1710 X-ray diffractometer. Surfaces of specimens after chronoamperometric tests were analyzed using a Raman spectrometer (Senterra, Bruker Optics) coupled with a Peltier cooled CCD detector $(576 \times 288$ pixels $)$ equipped with a $532 \mathrm{~nm}$ wavelength laser. The vanadium content of the test electrolytes after chronoamperometric testing was determined using a Spectro Genesis inductively coupled plasma-optical emitting spectrometer (ICP-OES).

\section{Results}

3.1. Potentiodynamic Polarisation Behaviour. Figures 1 and 2 show the potentiodynamic polarisation curves of the samples in $1 \mathrm{M} \mathrm{NaCl}$ and SMW, respectively. As was the case in a previous study, the anodic polarization behavior for each specimen was repeatable (Figure 3). The anodic polarization behavior in $\mathrm{NaCl}$, where all samples showed pseudopassive behavior, is similar to that observed in $\mathrm{HCl}$ acid solutions [8]. The pseudopassive behavior was more pronounced for the base alloy WC-10Co, the specimen with the least magnetic saturation (Table 1 ).

The pseudopassive behavior observed for WC-10Co hardmetal in the $\mathrm{NaCl}$ test solution is in contrast with other literatures [27] where dilute $(0.1 \mathrm{M}) \mathrm{NaCl}$ solutions were used. This is because the higher $\mathrm{Cl}^{-}$anion concentration used in this study compared to literature favours passivation [28].

Compared to $\mathrm{NaCl}$, anodic dissolution occurred continuously, without any pseudopassive behavior, for all specimens 


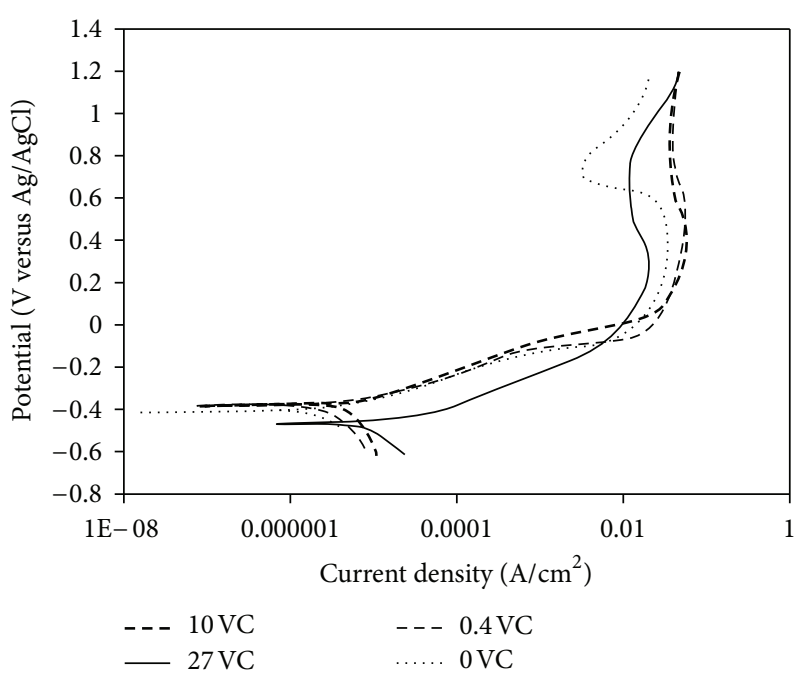

Figure 1: Potentiodynamic curves of the samples in $\mathrm{NaCl}$.

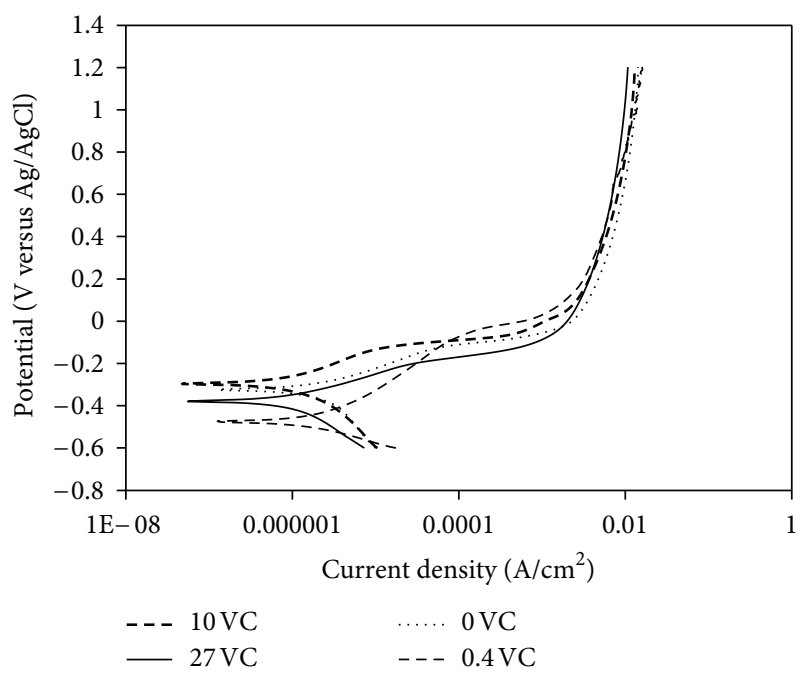

FIgURe 2: Potentiodynamic curves of the samples in SMW.

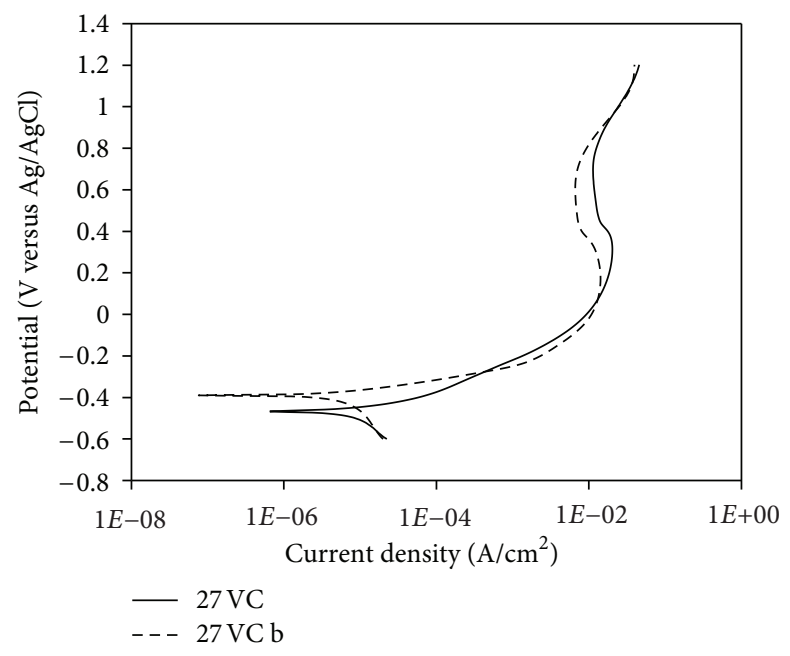

Figure 3: Repeatability of $27 \mathrm{wt} \% \mathrm{VC}$ in $1 \mathrm{M} \mathrm{NaCl}$. during potentiodynamic polarization in SMW (Figure 2). The behavior of the base alloy was in line with literature [9].

3.2. Corrosion Parameters. Table 3 presents the corrosion parameters of the specimens in $\mathrm{NaCl}$ and SMW. Vanadium carbide additions of $0.4 \mathrm{wt} \% \mathrm{VC}$, levels used for grain refinement, simultaneously made the $E_{\text {corr }}$ more negative, and the corrosion current density higher than that of the base alloy in both electrolytes. A similar trend was obtained in acidic solutions [8]. Higher VC contents made $E_{\text {corr }}$ nobler in $\mathrm{NaCl}$ compared to the base alloy. However, the corrosion current density increased and appeared to be independent of the VC content, an observation that was different from that found for $\mathrm{HCl}$ and $\mathrm{H}_{2} \mathrm{SO}_{4}$ acidic solutions which had a similar potentiodynamic polarization behavior and where current density decreased with increasing VC content [8].

There was no observable trend of the effect of increasing VC content on $E_{\text {corr }}$ in SMW: $10 \mathrm{wt} \%$ VC increased $E_{\text {corr }}$ to a more nobler value, while $27 \mathrm{wt} \% \mathrm{VC}$ decreased it to a lesser noble value, compared to the base alloy. However, the corrosion current densities decreased to values lower than those of the base alloy, the decrease tempered by the cobalt content.

3.3. Chronoamperometry Studies. Chronoamperometric tests were done at $0.8 \mathrm{~V}(\mathrm{v} \mathrm{SSE})$ for the base alloy and $0.7 \mathrm{~V}$ (v SSE) for the WC-VC-Co hardmetals in $1 \mathrm{M} \mathrm{NaCl}$ based on pseudopassivation at these potentials. Due to the continuous dissolution of all the samples during anodic polarization in SMW, a potential of $1.1 \mathrm{~V}$ ( $\mathrm{v}$ SSE) was used for all the samples. Figure 4 shows the variation of current density for tests in the $\mathrm{NaCl}$ solution. The base alloy passivated instantaneously and had the least steady state current density, unlike the VC specimens. VC additions at the level used for grain refinement ( $0.4 \mathrm{wt} \% \mathrm{VC})$ led to fluctuations in the current density curve, implying some pitting corrosion. The current for the high VC content alloys decreased quickly and then increased before decreasing again. Decreasing current densities are associated with a build-up of corrosion products on the test surface [29] while increases suggest oxidation events [17], that are caused by the fracture and/or fall off of the corrosion product that had formed on the surface to expose the underlying surface.

There was no instantaneous passivation for any specimen in SMW (Figure 5). In addition to the base alloy, 27VC also attained a steady state current density. As was the case in $\mathrm{NaCl}$ (Figure 4), the base alloy had the least steady state current. Current fluctuations were observed for specimen $0.4 \mathrm{VC}$, an indication of pitting, but the fluctuations were less pronounced than in $\mathrm{NaCl}$ (Figure 4).

3.4. Surface Phases after Corrosion. The results of the XRD patterns of the samples before corrosion have been published elsewhere [8]. Figures 6 and 7 are XRD patterns showing the change of surface phases after chronoamperometric testing in $\mathrm{NaCl}$ and SMW, respectively. Cobalt peaks, observed in all the specimens before corrosion, were absent after corrosion. This occurrence was in line with literature where 
TABLE 3: Electrochemical parameters of the WC-VC-Co samples in $\mathrm{NaCl}$ and SMW.

\begin{tabular}{lcccc}
\hline & $\mathrm{NaCl}$ & & \multicolumn{2}{c}{$\mathrm{SMW}$} \\
& $E_{\text {corr }}(\mathrm{V})(\mathrm{v} \mathrm{SSE})$ & $i_{\text {corr }}\left(\mu \mathrm{A} / \mathrm{cm}^{2}\right)$ & $E_{\text {corr }}(\mathrm{V})(\mathrm{v} \mathrm{SSE})$ & -0.313 \\
WC-10Co $_{\text {WC-0.4VC-10Co }}$ & -0.399 & 0.03 & -0.474 & 0.18 \\
WC-10VC-12C0 & -0.469 & 0.20 & -0.296 & 0.21 \\
WC-27VC-11Co & -0.370 & 0.36 & -0.379 & 0.15 \\
\hline
\end{tabular}

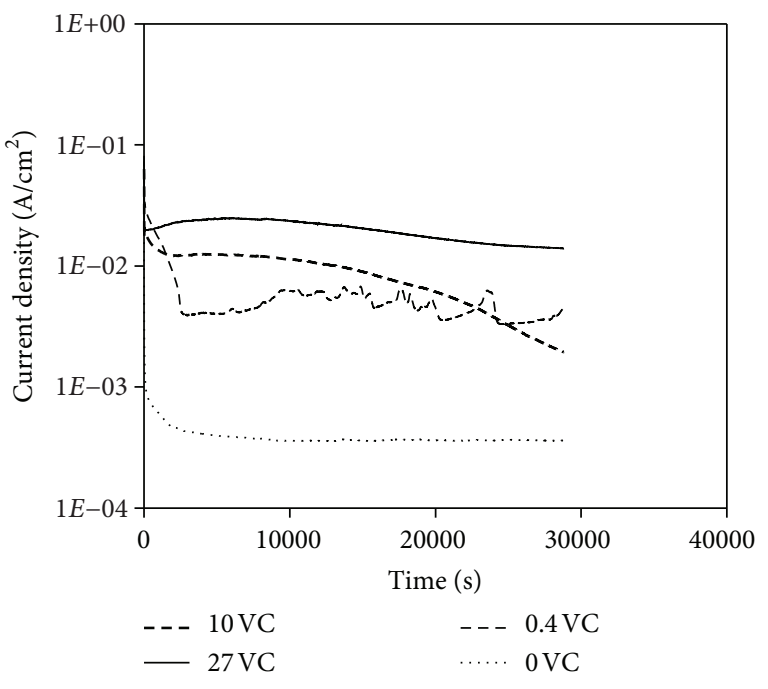

FIGURE 4: Chronoamperometry curves of the samples in $\mathrm{NaCl}$.

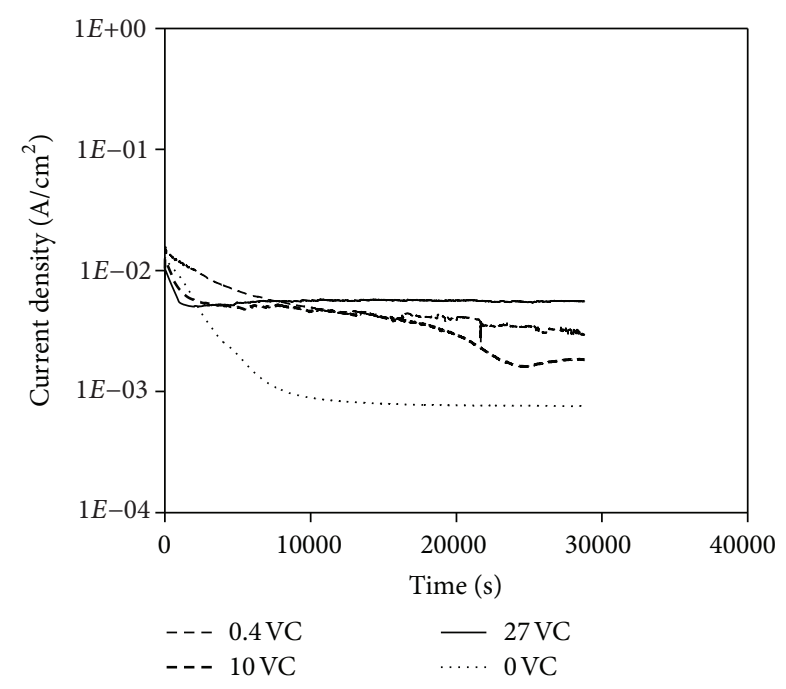

FIGURE 5: Chronoamperometry curves of samples in SMW.

the Co binder phase in WC-Co-based hardmetals corrodes preferentially [2]. Tungsten oxides appeared to have formed for some specimens, but the XRD analysis was inconclusive, necessitating further analysis using Raman spectroscopy (Figures 8 and 9). In contrast, there were no XRD peaks for vanadium-based corrosion phases on the surfaces of the
VC-containing specimens after corrosion in any of the test electrolyte (Figures 6 and 7).

Some of the VC-containing specimens did not have XRD peaks for $\mathrm{VC}$ (which occurs as $(\mathrm{V}, \mathrm{W}) \mathrm{C}$ ) after corrosion (10VC and 27VC) specimens in $\mathrm{NaCl}$ and 10VC in SMW as presented earlier in [8]). These peaks were present after corrosion in acid solutions, where corrosion rates were at least an order of magnitude higher than [8]. It is possible that in the current case, the $(\mathrm{V}, \mathrm{W}) \mathrm{C}$ grains fell out during specimen handling due to the dissolution of the binder, as has been observed in literature [30].

Figures 8 and 9 show the Raman spectra obtained on the samples after testing in $\mathrm{NaCl}$ and SMW, respectively. The corrosion products for all test specimens were tungstenoxide based, even though they had not been detected by XRD analysis in some cases, especially in SMW (Figure 7). Tables 4 and 5 allocate the Raman bands to their possible sources based on observations in literature. The literature of $\mathrm{WO}_{3}$ based films indicates that Raman bands below $190 \mathrm{~cm}^{-1}$ are caused by lattice vibration of crystalline $\mathrm{WO}_{3}$; bands between 190 and $400 \mathrm{~cm}^{-1}$ are due to bending of O-W-O bonds; those in the range $500-900 \mathrm{~cm}^{-1}$ are characteristic of stretching $\mathrm{O}-\mathrm{W}-\mathrm{O}$ bonds; and bands in the vicinity of 950 , characteristic of hydrated $\mathrm{WO}_{3}$, are caused by the stretching of terminal $\mathrm{W}=\mathrm{O}$ bonds $[16,17,19-21,31,32]$.

No Raman band matches were found for possible vanadium-based corrosion products, for example, vanadium oxide, vanadium oxy-chloride $\left(\mathrm{VOCl}_{3}\right)$, whose Raman bands are available in literature $[33,34]$. However, during the chronoamperometric tests, light green solids were observed to form in the solutions. Inductive coupled plasma optical emitting spectrometry (ICP-OES) analysis of the electrolytes indicated the presence of vanadium cations probably V(II) (Table 6) indicating that the green solids that formed were probably $\mathrm{VCl}_{2}$, which is known to be green [35].

The formation of $\mathrm{WO}_{3}$ as a film accounts for WC-VCCo pseudopassive behavior in acidic test media [8], and in the current study, the observation of pseudopassivity in the neutral $1 \mathrm{M} \mathrm{NaCl}$ test solution (Figure 1). Its formation on the specimens tested in SMW was however not accompanied by pseudopassive behaviour. The difference in pseudopassive behavior between the $\mathrm{NaCl}$ and SMW could have been caused by the difference in $\mathrm{Cl}^{-}$anion concentrations, where the higher concentrations in $\mathrm{NaCl}$ encouraged passivation compared to the low concentration obtained in the SMW [28]. It is also possible that the $\mathrm{WO}_{3}$ film formed in SMW had poorer adhesion properties. 


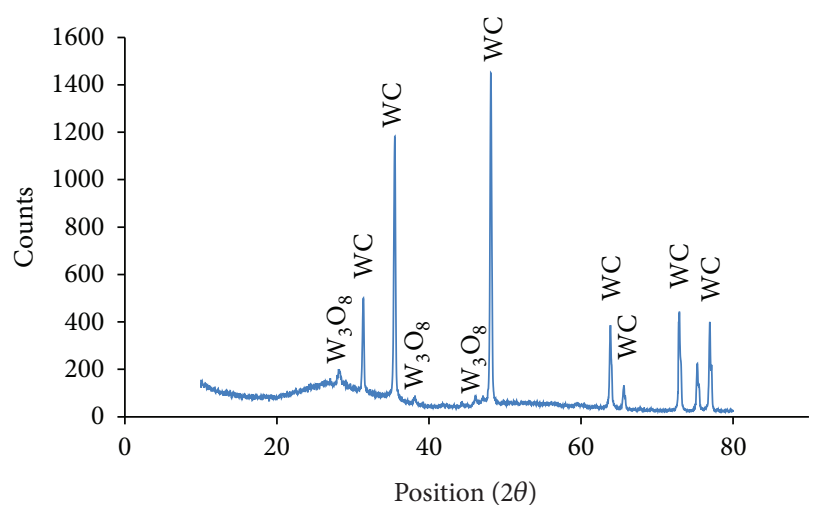

(a)

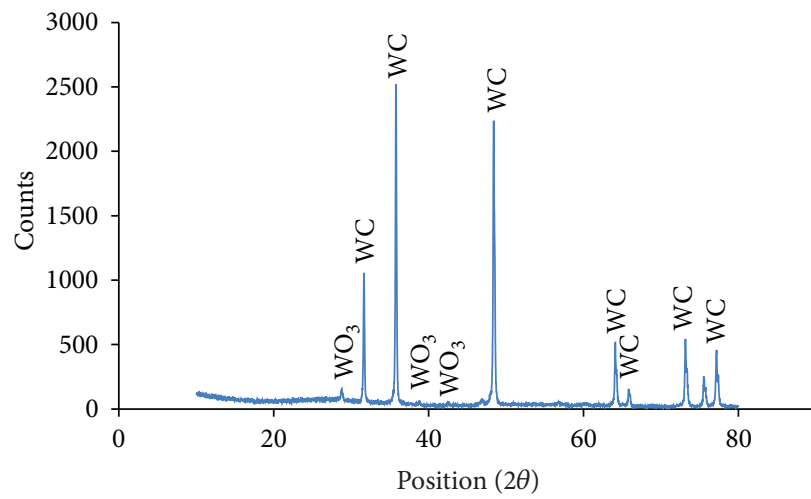

(c)

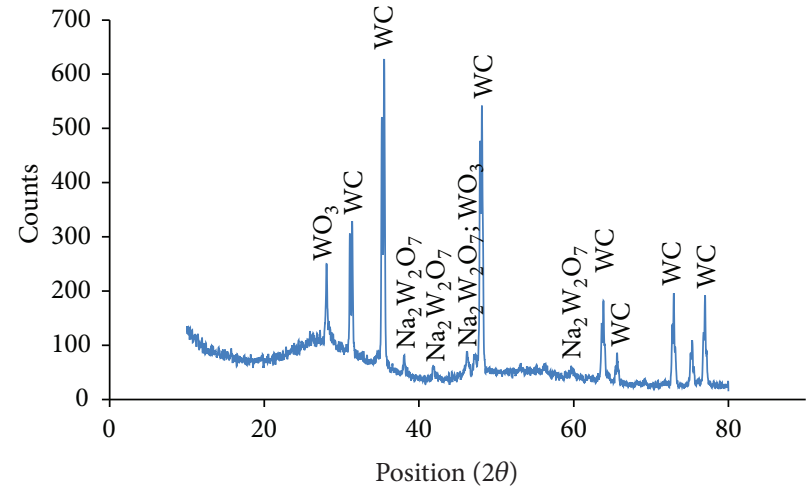

(b)

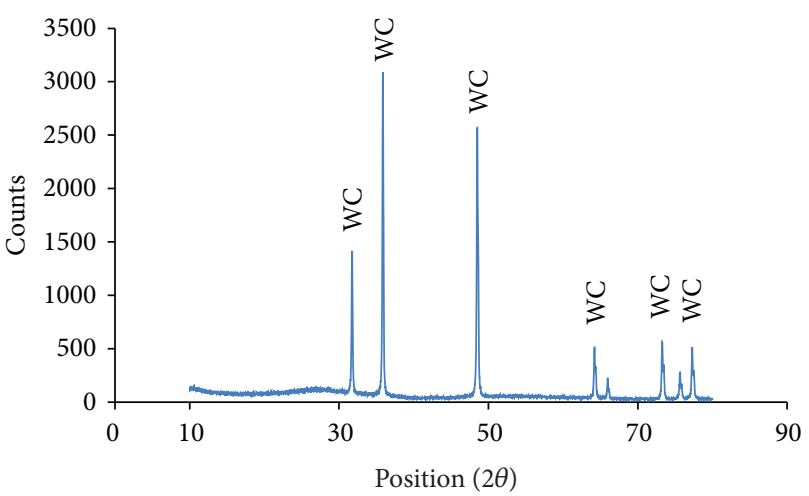

(d)

Figure 6: XRD pattern of the corrosion products of the samples on (a) WC-10Co, (b) WC-0.4VC-10Co, (c) WC-10VC-12Co, and (d) WC$27 \mathrm{VC}-11 \mathrm{Co}$ in $\mathrm{NaCl}$.

TABLE 4: Raman shifts after corrosion in $\mathrm{NaCl}$

\begin{tabular}{|c|c|c|c|}
\hline Specimen & Raman bands & Possible phase & References \\
\hline \multirow{3}{*}{ WC-10C } & $133 \& 249$ & $\mathrm{WO}_{3}$ & {$[16]$} \\
\hline & 814.5 & $\mathrm{WO}_{3}$ & {$[17]$} \\
\hline & $679 \& 958.5$ & $\mathrm{WO}_{3} \cdot 2 \mathrm{H}_{2} \mathrm{O}$ & {$[16]$} \\
\hline \multirow{5}{*}{ WC-0.4VC-10Co } & 131 & $\mathrm{WO}_{3}$ & {$[16]$} \\
\hline & 697 & $\mathrm{WO}_{3}$ & {$[18]$} \\
\hline & 813.5 & $\mathrm{WO}_{3}$ & {$[17]$} \\
\hline & 881.5 & $\mathrm{WO}_{3} \cdot \mathrm{nH}_{2} \mathrm{O}$ & {$[19]$} \\
\hline & 968.5 & $\mathrm{WO}_{3} \cdot 2 \mathrm{H}_{2} \mathrm{O}$ & {$[16]$} \\
\hline \multirow{2}{*}{ WC-10VC-12Co } & $131 \& 803$ & $\mathrm{WO}_{3}$ & {$[16]$} \\
\hline & $261 \& 962$ & $\mathrm{WO}_{3} \cdot 2 \mathrm{H}_{2} \mathrm{O}$ & [20] \\
\hline WC-27VC-11Co & $132.5,262.5,700, \& 805.5$ & $\mathrm{WO}_{3}$ & {$[16]$} \\
\hline
\end{tabular}

\section{General Discussion}

The effect of increasing amounts VC on the corrosion resistance of WC-Co appears to have been mixed. The VC reduces the extent of the pseudopassive behavior in $\mathrm{NaCl}$ and does not change it in SMW; it does not alter the corrosion current density in $\mathrm{NaCl}$, where the current density increases with Co content, while it reduces it in SMW; chronoamperometric current densities stabilize at higher values for specimens with VC. The trends in the results reported here suggest that VC impairs the corrosion resistance of WC-Co except in SMW where it reduces the current density. These results can be explained from two perspectives.

In general, it can be expected that VC additions affect the corrosion resistance of WC-Co in two ways. In the first instance, vanadium atoms from the VC can go into solution in the Co binder and either on their own and/or in conjunction with $\mathrm{W}$ atoms that also go in solution in the Co, alter the corrosion resistance of the Co binder. Solute atoms of $\mathrm{W}$ improve the corrosion resistance of Co [22]. This effect can 


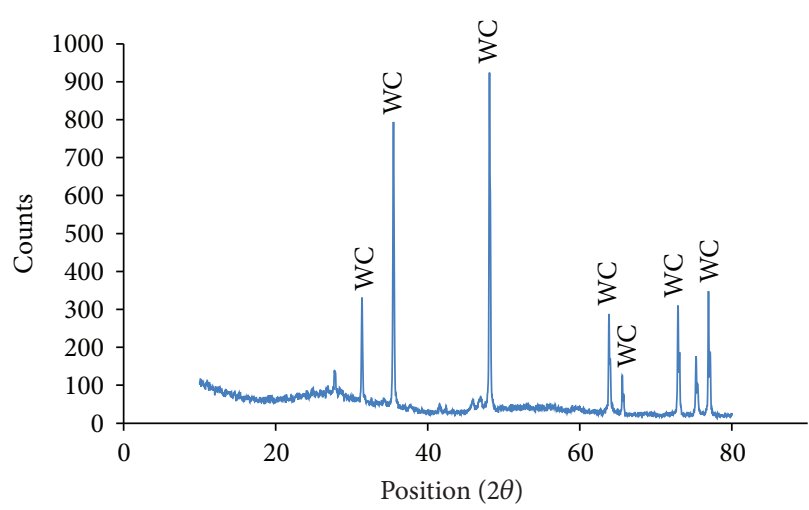

(a)

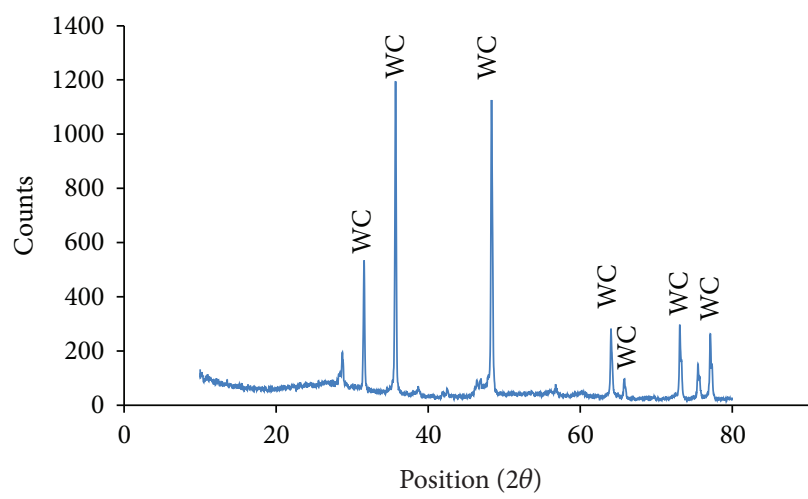

(c)

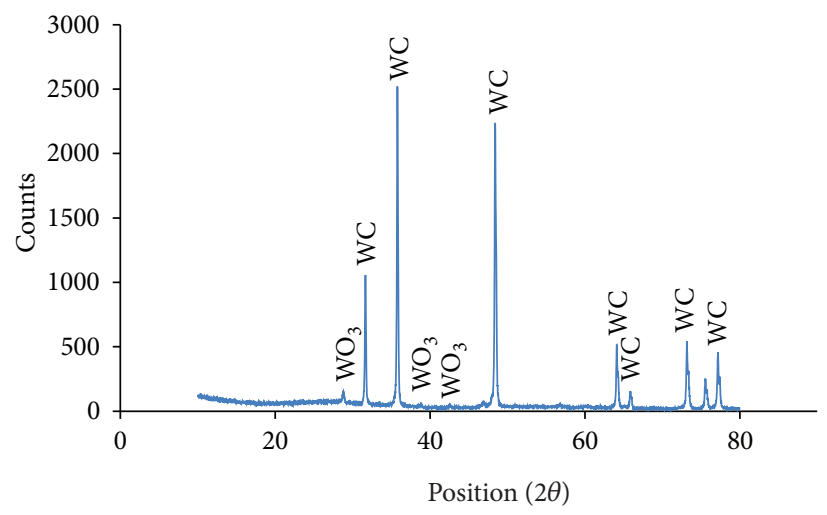

(b)

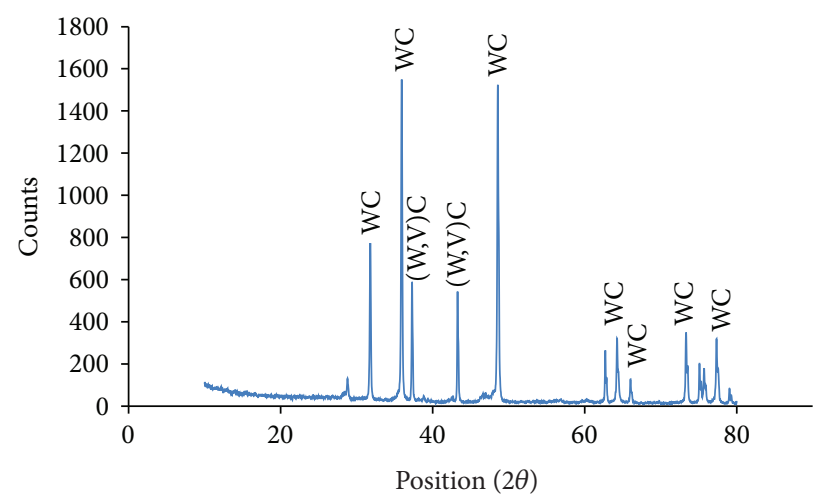

(d)

FIGURE 7: XRD pattern of the corrosion products of the samples on (a) WC-10Co, (b) WC-0.4VC-10Co, (c) WC-10VC-12Co, and (d) WC27VC-11Co in SMW.

TABLE 5: Raman bands after corrosion in SMW.

\begin{tabular}{lccc}
\hline Specimen & Raman bands & Possible phase & Reference \\
\hline WC-10Co & $133,262.5,704.5 \& 808$ & $\mathrm{WO}_{3}$ & {$[16,21]$} \\
\hline & 139 & $\mathrm{WO}_{3}$ & {$[21]$} \\
WC-0.4VC-10Co & 743 & $\mathrm{Cubic} \mathrm{WO}_{3}$ & {$[20]$} \\
& 891 & $\mathrm{WO}_{3}$ & {$[19]$} \\
& 955 & $\mathrm{WO}_{3} \cdot 2 \mathrm{H}_{2} \mathrm{O}$ & {$[16]$} \\
\hline WC-10VC-12Co & $129,263, \& 802$ & $\mathrm{WO}_{3}$ & {$[21]$} \\
WC-27VC-11Co & 980 & $\mathrm{WO}_{3} \cdot \mathrm{nH}_{2} \mathrm{O}$ & {$[22]$} \\
& $130,263,708, \& 803$ & $\mathrm{WO}_{3}$ & {$[21]$}
\end{tabular}

TABLE 6: ICP-OES results of VC containing corrosion product solutions after dissolution in SMW and $\mathrm{NaCl}$.

\begin{tabular}{lcc}
\hline \multirow{2}{*}{ Sample } & \multicolumn{2}{c}{ Vanadium content $(\mathrm{ppm})$} \\
& SMW & $\mathrm{NaCl}$ \\
\hline WC-0.4VC & $46.7 \pm 1.3$ & $83.1 \pm 3.5$ \\
WC-10VC & $15.1 \pm 3.7$ & $24.9 \pm 2.7$ \\
WC-27VC & $58.4 \pm 3.1$ & $2.0 \pm 0.3$ \\
\hline
\end{tabular}

either be augmented or curtailed by the presence of $\mathrm{VC}$ through its effect on the quantity of $\mathrm{W}$ atoms going into the
Co binder. The $\mathrm{W}$ solute content in Co can be determined from the magnetic saturation. It is known, broadly, that the magnetic saturation of conventional WC-Co increases with decreasing amounts of $\mathrm{W}$ atoms in Co [13, 14]. Judging from the magnetic saturations of the test specimens, which increase with VC content (Table 1), the introduction of VC reduced the amount of $\mathrm{W}$ atoms in the Co binders of these specimens.

The reduction of the $\mathrm{W}$ solute content of the binders of the VC specimens deduced above explains a number of the observations in this study. Some authors have used the $\mathrm{W}$ solute content, captured in the magnetic saturation, 


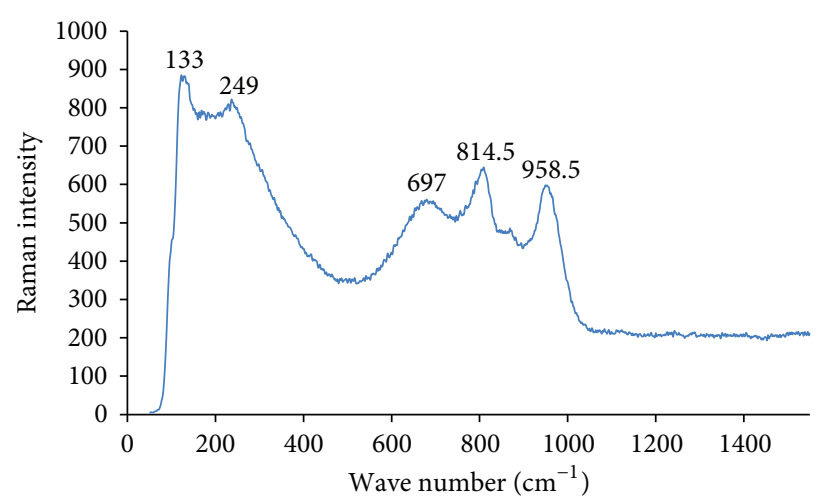

(a)

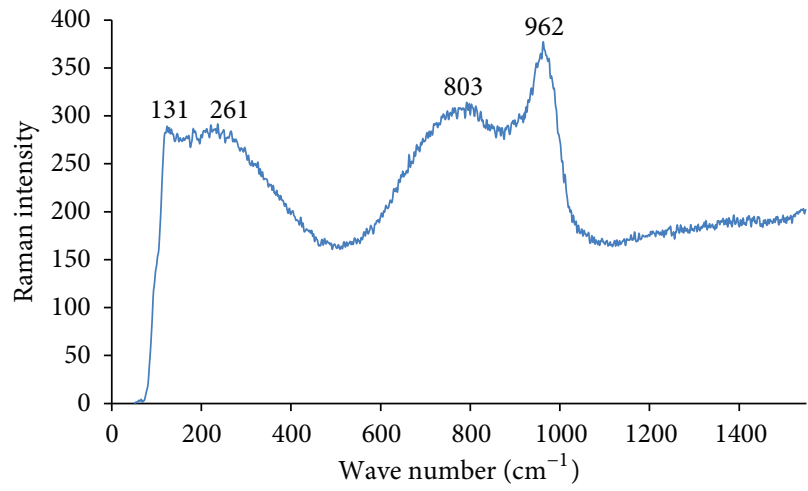

(c)

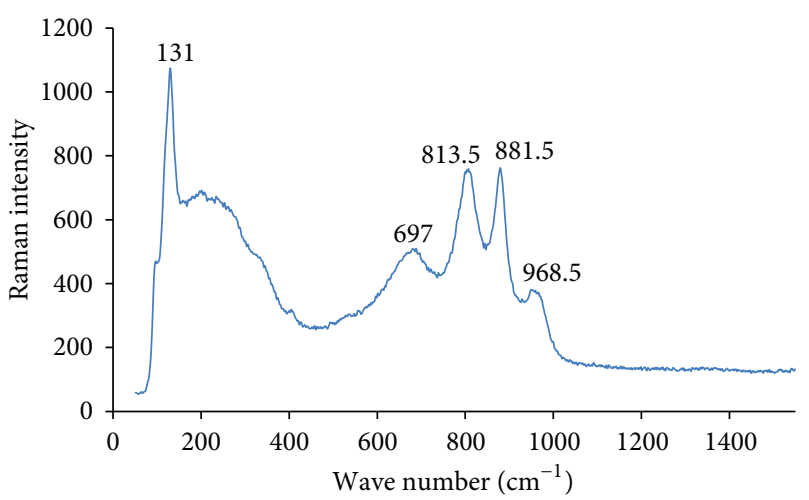

(b)

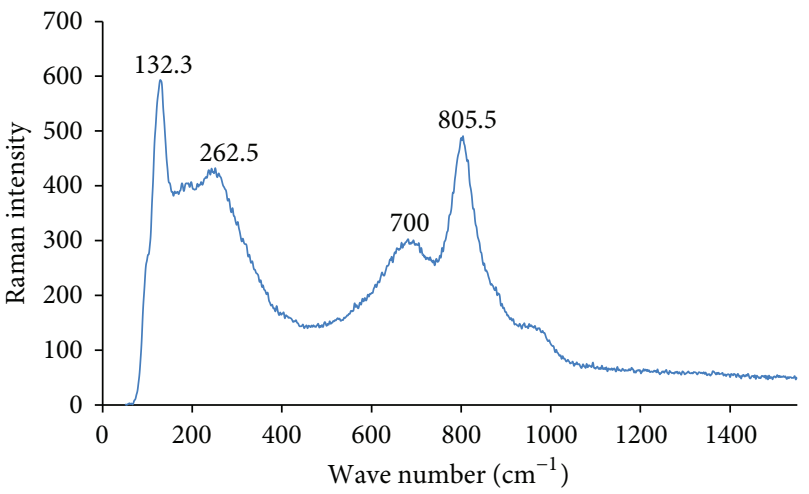

(d)

Figure 8: Raman spectra of corroded product on (a) WC-10Co, (b) WC-0.4VC-10Co, (c) WC-10VC-12Co, and (d) WC-27VC-11Co in $\mathrm{NaCl}$.

to explain the corrosion behavior of WC-Co. According to literature, a low magnetic saturation, implying a higher $\mathrm{W}$ solute content of the Co binder, is associated with a more pronounced pseudopassive behavior in sulphuric acid [36]. The pronounced pseudopassive behavior observed for the base alloy in $\mathrm{NaCl}$ in the current study (Figure 1) can therefore be explained on the basis of its lower magnetic saturation (Table 1) compared to the other test specimens. By extension, the variation of magnetic saturation also explains the variation of corrosion current densities, $i_{\text {corr }}$, in $\mathrm{NaCl}$ (Table 3), which increase with increasing magnetic saturation, that is, decreasing $\mathrm{W}$ solute content of the binder. This variation of current density associated with changing $\mathrm{W}$ solute content in Co is, as has already been mentioned, in line with literature, where lower Co binder $\mathrm{W}$ solute content is associated with poor corrosion resistance [22].

The above thinking where magnetic saturation/Co binder $\mathrm{W}$ solute content explains corrosion behavior needs to be qualified, because it does not appear like this is a universal phenomenon: the relationship appears to be solutionspecimen dependent. For example, corrosion of WC-Co in nitric acid is not explained by the magnetic saturation of the specimens [37]. The solution can play a role in accentuating the effect of the magnetic saturation. For example, the pronounced pseudopassive behavior observed for corrosion of the base alloy in $\mathrm{NaCl}$ in this study could have been aided by the effect of higher $\mathrm{Cl}^{-}$ion concentration, which also encourages pseudopassive behavior [28].

The specificity of the solution-specimen dependence of the effect of magnetic saturation on corrosion, referred to above, appears to partly apply to the corrosion behavior in SMW, where all specimens continuously dissolved during potentiodynamic polarization (Figure 2) and also where, generally, corrosion current densities, $i_{\text {corr }}$, decreased even as the magnetic saturation was increasing (Table 3). The $\mathrm{Cl}^{-}$ ion concentration in the SMW was much less, preventing the solution from predisposing specimens to pseudopassive behavior. The variation of $i_{\text {corr }}$, in SMW can be loosely correlated with the variation of the volume fraction of the binder, meaning that the effect of VC on corrosion in SMW was probably through its effect on the volume fraction of the binder.

The second possible impact of the $\mathrm{VC}$ on the corrosion of WC-Co hardmetal would be expected to be through its effect on the corrosion product. It has been suggested that vanadium is naturally passivating [38]. However, this tendency did not manifest itself in this study: for example, the potentiodynamic polarization behavior of the specimens was 


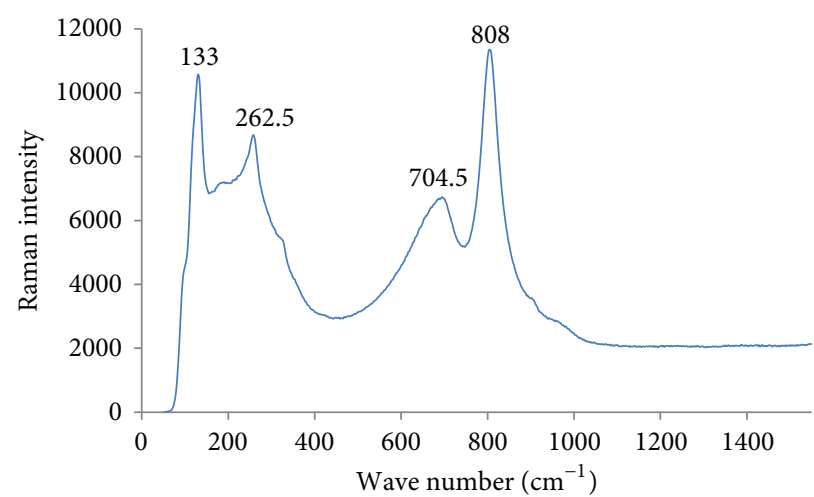

(a)

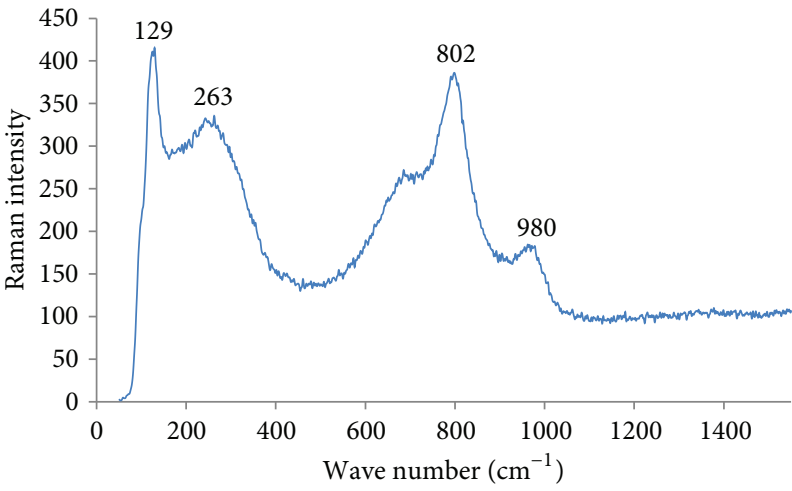

(c)

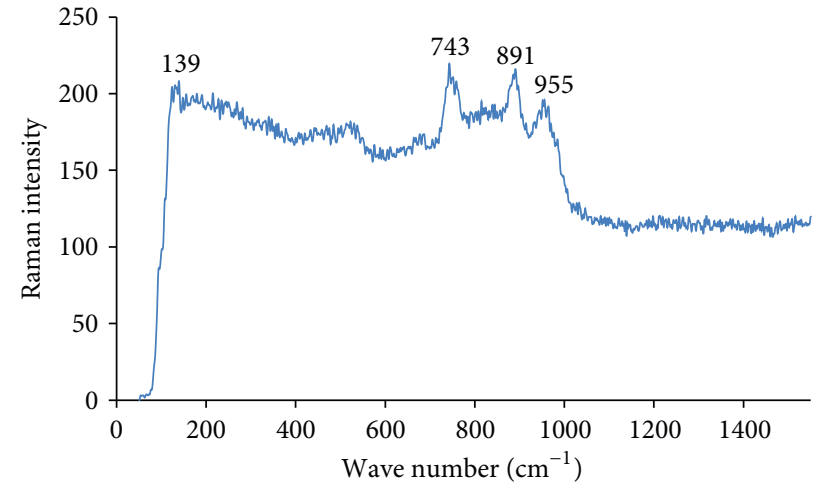

(b)

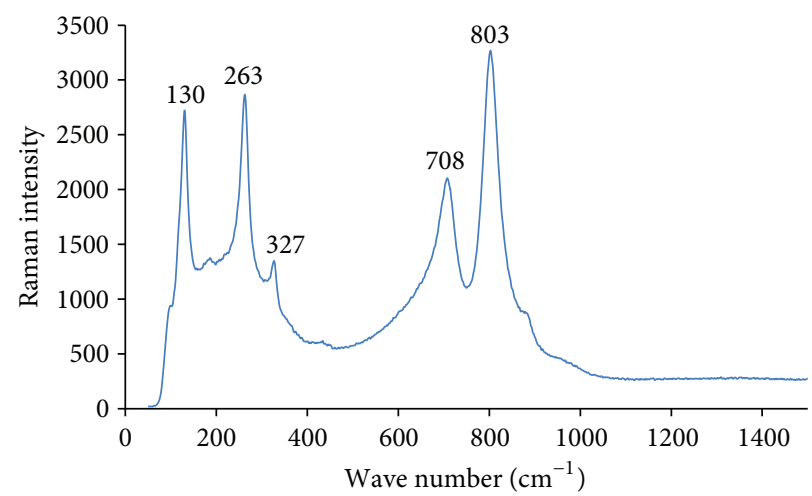

(d)

Figure 9: Raman spectra of after corrosion in SMW (a) WC-10Co, (b) WC-0.4VC-10Co, (c) WC-10VC-12Co, and (d) WC-27VC-11Co.

not changed in a positive way, for example, the emergence of true passivity, by the presence of VC (Figures 1 and 2). Also, no vanadium-based compound was detected on the corroded surfaces of the specimens in this study either by XRD studies (Figures 6 and 7) or by Raman spectroscopy (Figures 8 and 9). These two analysis techniques showed that no solid film of a vanadium compound formed on the surfaces of the test specimens after corrosion. It appears that a vanadium-based corrosion compound formed during corrosion, however, it dissolved in the test solutions (as shown by the presence of Vanadium ions in the test electrolytes (Table 6)), and, in some cases, precipitated out of the electrolytes and did not participate in forming a barrier to curtail corrosion. This failure to form a corrosion barrier explains the higher current densities observed for the VC specimens during chronoamperometric testing (Figures 4 and 5).

The results of the $0.4 \mathrm{wt} \% \mathrm{VC}$ specimen deserve some emphasis, given the importance of $\mathrm{VC}$-grain refinement of WC-Co materials. Fine-grained WC-Co materials are important for wear applications. While the wear resistance is high, the current results have shown that the corrosion resistance is poorer than for any other specimen in the study. This specimen had a higher corrosion current density, in both electrolytes (Table 3), and was the only specimen that pitted during chronoamperometric testing (Figures 4 and 5).
Even though this has been reported in the literature of the corrosion of WC-Co in neutral chloride solutions $[6,9]$, the behavior had not been effectively explained. This detrimental effect stems, primarily, from the effect of $\mathrm{VC}$ on the Co binder $\mathrm{W}$ solute content: the $\mathrm{VC}$ restricts the amount of $\mathrm{W}$ that goes into solution in the Co binder during sintering by forming a $(\mathrm{V}, \mathrm{W}) \mathrm{C}$ film around the $\mathrm{WC}$ grains. This is the mechanism by which VC grain refiners are known to effect WC grain refinement [38]. The effect of low W solute content on corrosion has already been explained.

\section{Conclusion}

Investigations into the corrosion behaviour of WC-VC-Co hardmetals using potentiodynamic scans, XRD, and Raman spectroscopy measurements in $1 \mathrm{M} \mathrm{NaCl}$ and synthetic mine water (SMW) were undertaken. The observations can be summarized as follows.

(i) Specimens exhibit active-pseudopassive behavior in $\mathrm{NaCl}$ but the intensity of the pseudopassivation is impaired by the presence of VC. In SMW, all specimens actively corrode during anodic polarization with no impact whatsoever from VC. The negative impact in $\mathrm{NaCl}$ and the lack of impact in SMW are 
caused, primarily, by the fact that the VC does not participate in the formation of a protective film on the surfaces of the corroding samples, and, partly by the fact that the VC prevents $\mathrm{W}$ atoms from going into solution in the Co binder, that is, the VC fails to lower the magnetic saturation of samples.

(ii) Additions of VC to WC-Co at levels used for WC grain size refinement increase corrosion current densities and predispose specimens to pitting corrosion. This occurs because the VC reduces the amount of $\mathrm{W}$ atoms dissolving in the Co binder (increases the magnetic saturation compared to the base alloy).

(iii) The effect of high VC content on the corrosion resistance of WC-Co is solution dependent: high VC contents are not beneficial for corrosion resistance in $\mathrm{NaCl}$, but greatly improve corrosion resistance in SMW.

\section{Acknowledgments}

This work was funded by South Africa's DST's Centre of Excellence in Strong Materials, based at the University of the Witwatersrand, Johannesburg, and the National Research Foundation.

\section{References}

[1] H. Engqvist, U. Beste, and N. Axén, "Influence of $\mathrm{pH}$ on sliding wear of WC-based materials," International Journal of Refractory Metals and Hard Materials, vol. 18, no. 2, pp. 103-109, 2000.

[2] M. H. Ghandehari, "Anodic behavior of cemented WC-6\% co alloy in phosphoric acid solutions," Journal of the Electrochemical Society, vol. 127, no. 10, pp. 2144-2147, 1980.

[3] W. J. Tomlinson and C. R. Linzell, "Anodic polarization and corrosion of cemented carbides with cobalt and nickel binders," Journal of Materials Science, vol. 23, no. 3, pp. 914-918, 1988.

[4] A. Human, I. Northrop, S. Luyckx, and M. James, "A comparison between cemented carbides containing cobalt- and nickelbased binders," Journal of Hard Materials, vol. 2, no. 3, pp. 245-256, 1991.

[5] J. H. Potgieter, N. Thanjekwayo, P. Olubambi, N. Maledi, and S. S. Potgieter-Vermaak, "Influence of $\mathrm{Ru}$ additions on the corrosion behaviour of WC-Co cemented carbide alloys in sulphuric acid," International Journal of Refractory Metals and Hard Materials, vol. 29, no. 4, pp. 478-487, 2011.

[6] W. J. Tomlinson and N. J. Ayerst, "Anodic polarization and corrosion of WC-Co hardmetals containing small amounts of $\mathrm{Cr}_{3} \mathrm{C}_{2}$ and/or VC," Journal of Materials Science, vol. 24, no. 7, pp. 2348-2352, 1989.

[7] S. Broccardo, An investigation into the corrosion resistance of WC-VC-Co hardmetals [M.Sc. thesis], University of the Witwatersrand, 2003.

[8] D. S. Konadu, J. V. D. Merwe, J. H. Potgieter, S. PotgieterVermaak, and C. N. Machio, "The corrosion behaviour of WCVC-Co hardmetals in acidic media," Corrosion Science, vol. 52, no. 9, pp. 3118-3125, 2010.

[9] A. M. Human and H. E. Exner, "The relationship between electrochemical behaviour and in-service corrosion of WC based cemented carbides,' International Journal of Refractory Metals and Hard Materials, vol. 15, no. 1-3, pp. 65-71, 1997.

[10] H. E. Exner, "Physical and chemical nature of cemented carbides," International metals reviews, vol. 24, no. 4, pp. 149-173, 1979.

[11] A. M. Human and H. E. Exner, "Electrochemical behaviour of tungsten-carbide hardmetals," Materials Science and Engineering A, vol. 209, no. 1-2, pp. 180-191, 1996.

[12] M. T. Laugier, "Coercivity, hardness and microstructure in WCCo composites," Journal of Materials Science Letters, vol. 4, no. 2, pp. 211-216, 1985.

[13] D. L. Tillwick and I. Joffe, "Precipitation and magnetic hardening in sintered WC-Co composite materials," Journal of Physics D, vol. 6, no. 13, pp. 1585-1596, 1973.

[14] B. Roebuck, E. A. Almond, and A. M. Cottenden, "The influence of composition, phase transformation and varying the relative F.C.C. and H.C.P. phase contents on the properties of dilute CoWC alloys," Materials Science and Engineering, vol. 66, no. 2, pp. 179-194, 1984.

[15] C. N. Machio, Preparation, characterisation and testing of WC-VC-Co HP/HVOF thermal spray coatings [Ph.D. thesis], University the Witwatersrand, 2006.

[16] P. Delichere, P. Falaras, M. Froment, A. Hugot-Le Goff, and B. Agius, "Electrochromism in anodic $\mathrm{WO}_{3}$ films I: preparation and physicochemical properties of films in the virgin and coloured states," Thin Solid Films, vol. 161, pp. 35-46, 1988.

[17] B. Bozzini, G. Pietro De Gaudenzi, A. Fanigliulo, and C. Mele, "Electrochemical oxidation of WC in acidic sulphate solution," Corrosion Science, vol. 46, no. 2, pp. 453-469, 2004.

[18] T. Kubo and Y. Nishikitani, "Deposition temperature dependence of optical gap and coloration efficiency spectrum in electrochromic tungsten oxide films," Journal of the Electrochemical Society, vol. 145, no. 5, pp. 1729-1734, 1998.

[19] G. N. Kustova, Y. A. Chesalov, L. M. Plyasova, I. Y. Lin, and A. I. Nizovskii, "Vibrational spectra of $\mathrm{WO}_{3} \cdot \mathrm{nH}_{2} \mathrm{O}$ and $\mathrm{WO}_{3}$ polymorphs," Vibrational Spectroscopy, vol. 55, no. 2, pp. 235-240, 2011.

[20] J. A. Horsley, I. E. Wachs, J. M. Brown, G. H. Via, and F. D. Hardcastle, "Structure of surface tungsten oxide species in the $\mathrm{WO}_{3} / \mathrm{Al}_{2} \mathrm{O}_{3}$ supported oxide system from X-ray absorption near-edge spectroscopy and Raman spectroscopy," Journal of Physical Chemistry, vol. 91, no. 15, pp. 4014-4020, 1987.

[21] K. Nonaka, A. Takase, and K. Miyakawa, "Raman spectra of sol-gel-derived tungsten oxides," Journal of Materials Science Letters, vol. 12, no. 5, pp. 274-277, 1993.

[22] A. M. Human, B. Roebuck, and H. E. Exner, "Electrochemical polarisation and corrosion behaviour of cobalt and $\mathrm{Co}(\mathrm{W}, \mathrm{C})$ alloys in $1 \mathrm{~N}$ sulphuric acid," Materials Science and Engineering A, vol. 241, no. 1-2, pp. 202-210, 1998.

[23] C. Colin, L. Durant, N. Favrot, J. Besson, G. Barbier, and F. Delannay, "Processing of functional-gradient WC-Co cermets by powder metallurgy," International Journal of Refractory Metals and Hard Materials, vol. 12, no. 3, pp. 145-152, 1993.

[24] C. Allen, "Corrosion of galvanised steel in synthetic mine waters," British Corrosion Journal, vol. 26, no. 2, pp. 93-101, 1991.

[25] S. Yeo, D. J. Kim, and J. W. Park, "Enhanced corrosion resistance of WC-Co with an ion beam mixed silicon carbide coating," International Journal of Refractory Metals and Hard Materials, vol. 29, no. 5, pp. 582-585, 2011. 
[26] S. Hochstrasser-Kurz, Y. Mueller, C. Latkoczy, S. Virtanen, and P. Schmutz, "Analytical characterization of the corrosion mechanisms of WC-Co by electrochemical methods and inductively coupled plasma mass spectroscopy," Corrosion Science, vol. 49, no. 4, pp. 2002-2020, 2007.

[27] B. Schnyder, C. Stössel-Sittig, R. Kötz et al., "Investigation of the electrochemical behaviour of WC-Co hardmetal with electrochemical and surface analytical methods," Surface Science, vol. 566-568, no. 1-3, pp. 1240-1245, 2004.

[28] V. Mitrovic-Scepanovic, B. MacDougall, and M. J. Graham, "The effect of $\mathrm{Cl}^{-}$ions on the passivation of $\mathrm{Fe} 26 \mathrm{Cr}$ alloy," Corrosion Science, vol. 27, no. 3, pp. 239-247, 1987.

[29] B. Bozzini, G. P. De Gaudenzi, A. Fanigliulo, and C. Mele, "Anodic behaviour of WC-Co type hardmetal," Materials and Corrosion, vol. 54, no. 5, pp. 295-303, 2003.

[30] D. Zur Megede and E. Heitz, "Das korrosionsverhalten von Hartmetall-Verbundwerkstoffen in chloridhaltigen wäßrigen lösungen," Materials and Corrosion, vol. 37, no. 5, pp. 207-214, 1986.

[31] M. F. Daniel, B. Desbat, J. C. Lassegues, B. Gerand, and M. Figlarz, "Infrared and Raman study of WO3 tungsten trioxides and $\mathrm{WO}_{3} \cdot \mathrm{xH}_{2} \mathrm{O}$ tungsten trioxide tydrates," Journal of Solid State Chemistry, vol. 67, no. 2, pp. 235-247, 1987.

[32] D. S. Kim, M. Ostromecki, and I. E. Wachs, "Surface structures of supported tungsten oxide catalysts under dehydrated conditions," Journal of Molecular Catalysis A, vol. 106, no. 1-2, pp. 93-102, 1996.

[33] F. D. Hardcastle and I. E. Wachs, "Determination of vanadiumoxygen bond distances and bond orders by Raman spectroscopy," Journal of Physical Chemistry, vol. 95, no. 13, pp. 5031-5041, 1991.

[34] M. A. Vuurman, D. J. Stufkens, A. Oskam, G. Deo, and I. E. Wachs, "Combined Raman and IR study of $\mathrm{MOx}-\mathrm{V}_{2} \mathrm{O}_{5} / \mathrm{Al}_{2} \mathrm{O}_{3}$ $\left(\mathrm{MOx}=\mathrm{MoO}_{3}, \mathrm{WO}_{3}, \mathrm{NiO}, \mathrm{CoO}\right)$ catalysts under dehydrated conditions," Journal of the Chemical Society-Faraday Transactions, vol. 92, no. 17, pp. 3259-3265, 1996.

[35] C. K. Gupta and N. Krishnamurthy, Extractive Metallurgy of Vanadium, Elsevier Science Publishers B.V., Amsterdam, The Netherlands, 1992.

[36] S. Sutthiruangwong and G. Mori, "Corrosion properties of Co-based cemented carbides in acidic solutions," International Journal of Refractory Metals and Hard Materials, vol. 21, no. 3-4, pp. 135-145, 2003.

[37] E. Breval, J. P. Cheng, D. K. Agrawal et al., "Comparison between microwave and conventional sintering of WC/Co composites," Materials Science and Engineering A, vol. 391, no. 1-2, pp. 285-295, 2005.

[38] I. Sugiyama, Y. Mizumukai, T. Taniuchi et al., "Formation of $(\mathrm{W}, \mathrm{V}) \mathrm{Cx}$ layers at the WC/Co interfaces in the VC-doped WC-Co cemented carbide," International Journal of Refractory Metals and Hard Materials, vol. 30, no. 1, pp. 185-187, 2012. 

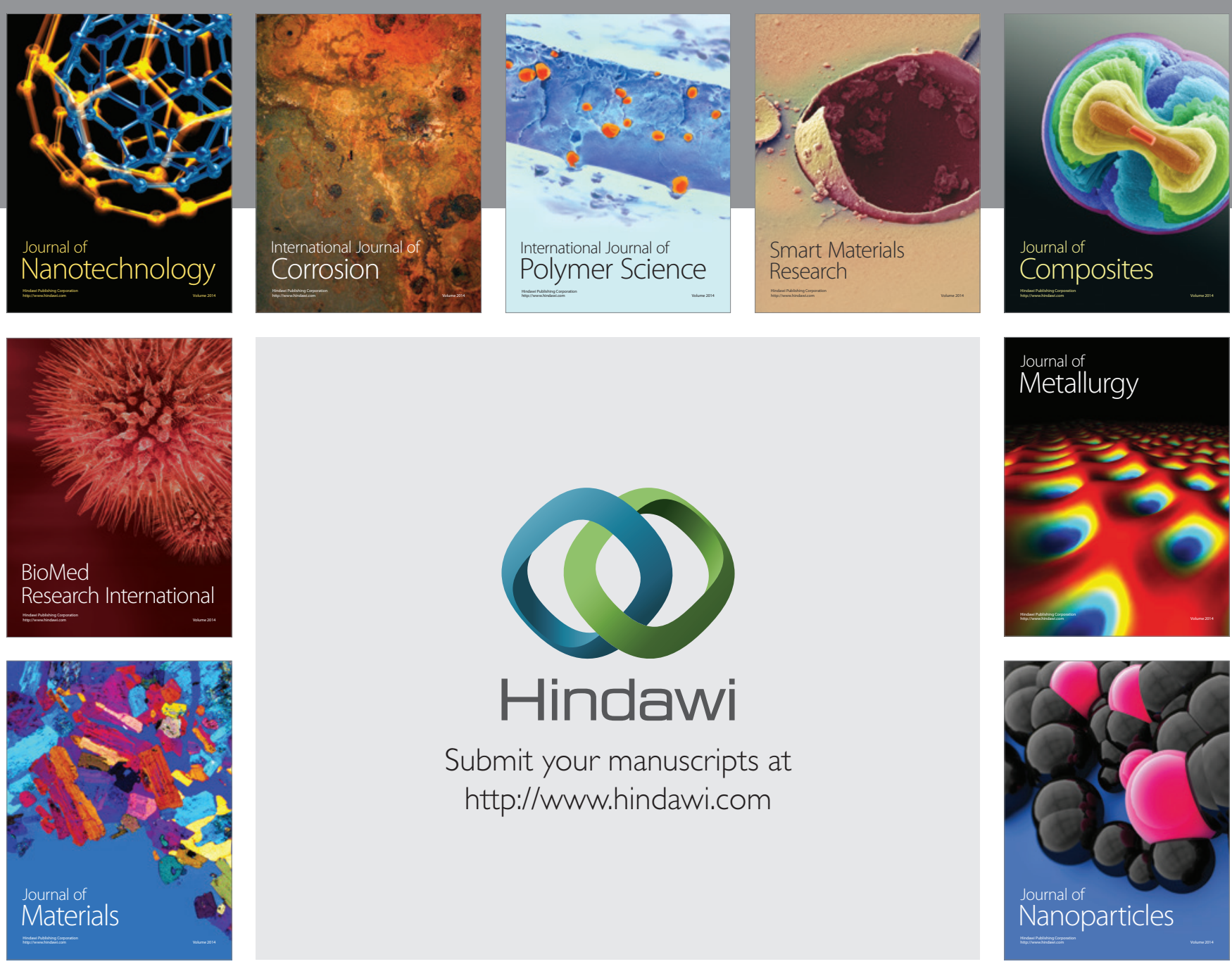

Submit your manuscripts at http://www.hindawi.com
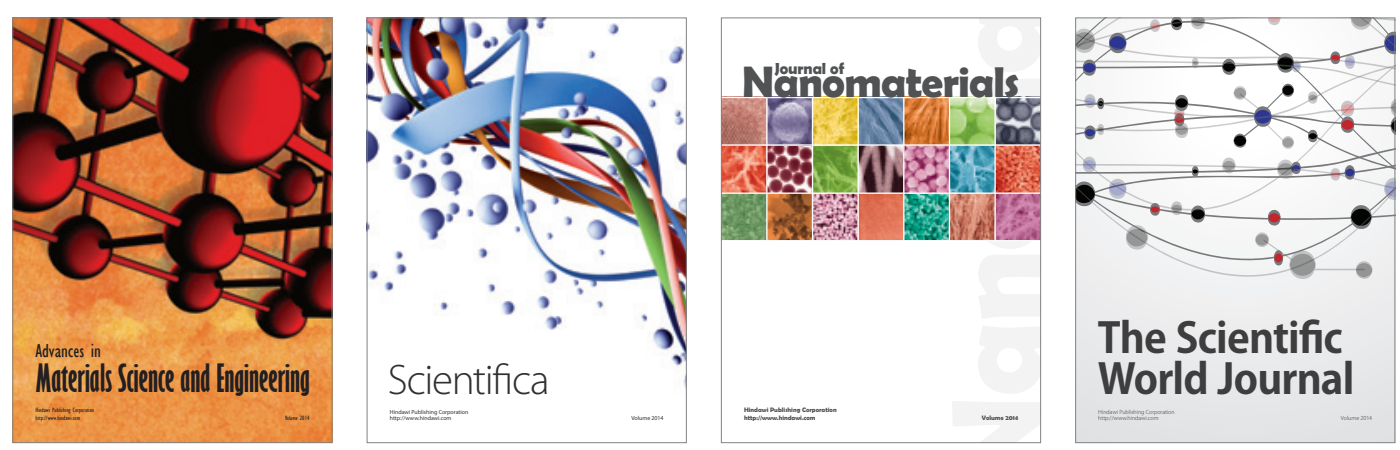

\section{The Scientific World Journal}
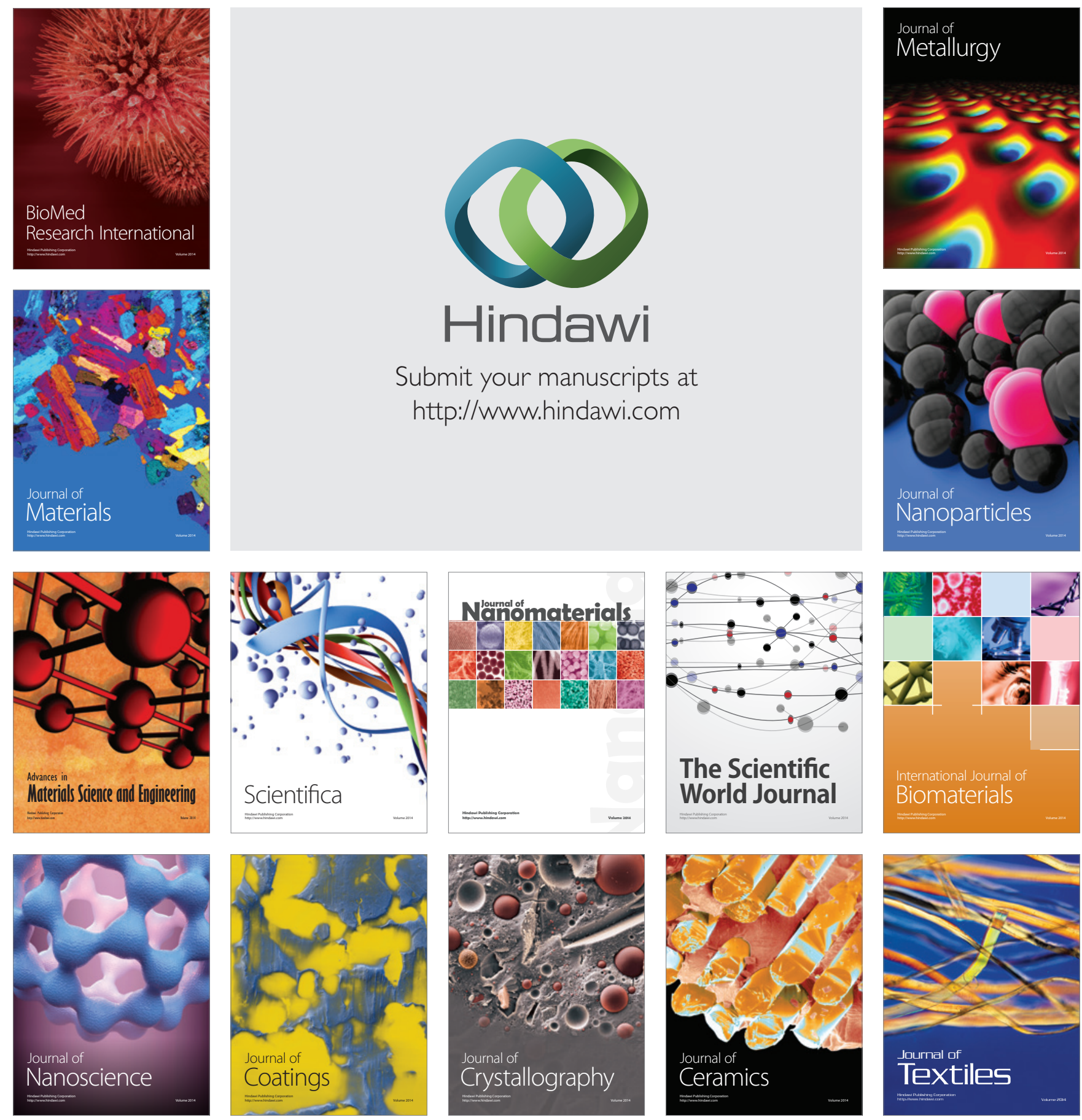